\title{
SISTEM PENDUKUNG KEPUTUSAN DALAM PENENTUAN JABATAN KAPOLRES DI JAJARAN KEPOLISIAN DAERAH SUMATERA UTARA (POLDA SUMUT)DENGAN METODE SIMPLE ADDITIVE WEIGHT (SAW)
}

\author{
Jijon Raphita Sagala ${ }^{1}$, Guntur Syahputra ${ }^{2}$ \\ ${ }^{1}$ Teknik Informatika \\ ${ }^{2}$ Manajemen Informatika \\ STMIK Pelita Nusantara Medan Jl. Iskandar Mudan No 1 Medan, Sumatera Utara, 20154 \\ Indonesia \\ sisagala@gmail.com ${ }^{1}$, guntur_capt@yahoo.co.id ${ }^{2}$
}

\begin{abstract}
Abstrak
Jabatan di kepolisian dalam fungsi jabatan, dimulai setelah organisasi melaksanakan kegiatan penarikan dan seleksi, yaitu pada saat seorang calon anggota Kepolisian dinyatakan diterima dan siap untuk ditempatkan pada jabatan atau unit kerja yang sesuai dengan satuan pendidikan. Namun ternyata permasalahannya tidak sesederhana itu, karena justru keberhasilan dari keseluruhan program pemilihan jabatan terletak pada ketepatan dalam menempatkan personil yang bersangkutan. Proses penempatan merupakan suatu proses yang sangat menentukan dalam mendapatkan jabatan yang kompeten yang dibutuhkan, karena penempatan yang tepat akan dapat membantu perusahaan atau instansi dalam mencapai tujuan yang diharapkan. Dengan metode Simple Additive Weighting (SAW) dapat membantu pihak pengambil keputusan dalam memilih calon Kapolres yang benar-benar sesuai dengan kriteria yang dibutuhkan oleh instansi kepolisian. Sehingga dengan sistem ini Polda Sumut dapat meminimalisasi kesalahan yang diakibatkan oleh kinerja Personil Kepolisian, yaitu dengan cara menempatkan personil pada posisi atau bidang yang sesuai dengan kemampuannya.
\end{abstract}

Kata Kunci : Simple Additive Weighting (SAW), Kapolres, Sistem Pendukung Keputusan

\section{Abstract}

Office in policing in the functions of Office, started after the Organization carry out the withdrawal and selection, that is, at the moment a prospective member of the police force was declared acceptable and ready to be placed on the Office or work unit in accordance with the educational unit.But it turns out that the problem is not that simple, because it is precisely the success of the overall program of the election office is located on the accuracy in placing personnel concerned.The placement process is a process that is crucial in getting the competent Office is required, because the proper placement will be able to help companies or agencies in achieving the expected objectives. With the method of Simple Additive Weighting $(S A W)$ can assist decision makers in selecting prospective Kapolres who really fit the criteria required by police agencies.So with this system of North Sumatra Police can minimize errors caused by the performance of the Police Personnel, that is, by the way puts personnel at the position or field in accordance with its ability.

Keywords: Simple Additive Weighting (SAW), Kapolres, Decision Support System

\section{PENDAhuluan}

Kepolisian Daerah Sumatera Utara merupakan salah satu instansi pemerintahan di Medan yang bergerak dalam bidang pelayaanan, perlindungan dan pengayoman masyarakat. Dimana selama ini pada proses penempatan jabatan hanya dilihat dari hasil tes dan beberapa persyaratan dasar lainnya. Sebagian besar personil mengalami kesulitan beradaptasi dengan tugas-tugas yang harus dilaksanakan karena tidak memiliki latar belakang pengetahuan yang sesuai dengan posisi yang ditempatinya. Jika dibiarkan terus menerus, hal ini akan berdampak negatif pada pelayanan keamanan yang diberikan dan menghambat kemajuan Kepolisian Daerah Sumatera Utara. Oleh karena itu, pihak Polda Sumut mencari solusi agar dapat meminimalisasi kesalahan yang diakibatkan oleh kinerja Personil Kepolisian, yaitu dengan cara menempatkan personil pada posisi atau bidang yang sesuai dengan kemampuannya.

Untuk menentukan jabatan dilingkungan kepolisian telah diatur dalam Peraturan Kapolri No 17 Tahun 2010 dibentuk sebuah badan yang diberi nama Badan Pertimbangan Jabatan dan 
kepangangkatan (Baperjakat) untuk Tingkat Pusat, Tingkat Satuan Induk Organisasi dan Tingkat Wilayah.

Memahami Sistem Pendukung Keputusan dan penggunaannya sebagai sistem yang menunjang dan mendukung keputusan dan komputer guna mengetahui bidang fungsi masing-masing. Tujuan pembetukan Sistem Pendukung Keputusan yang efektif adalah memanfaatkan keunggulan kedua unsur, yaitu manusia dan perangkat elektronik. Terlalu banyak menggunakan komputer akan mengahasilkan pemecahan yang bersifat yang tidak fleksibel, dan keputusan yang dangkal. Sedangkan terlalu banyak pertimbangan dari sisi manusia akan memunculkan reaksi yang lamban, pemanfaatan data yang serba terbatas, dan kelambanan dalam mengkaji alternative yang relevan. Oleh karena itulah diperlukan sebuah pendekatan atau metode yang dapat menyatukan unsur manusia dan perangkat keras atau elektronik dalam suatu sistem pendukung keputusan untuk mengambil sebuah keputusan yang paling sesuai.

Sistem Pendukung Keputusan yang akan dibuat menggunakan metode yang digunakan dalam menghadapi situasi Multiple Decision Making(MADM) yaitu metode SAW (Simple Additive Weighting) Konsep Dasar metode ini adalah mencari penjumlahan bobot dari rating kinerja pada setiap alternative pada semua atribut.

\section{TINJAUAN PUSTAKA}

\section{A. Pengertian Kapolda dan Kapolres}

Kepolisian Daerah (Polda) merupakan satuan pelaksana utama Kewilayahan yang berada di bawah Kapolri. Polda bertugas menyelenggarakan tugas Polri padatingkat kewilayahan tingkat I seperti Provinsi atau Daerah Istimewa. Polda merupakan perpanjangan tanganlang sungdari MabesPolri. Polda dipimpin oleh Kepala Kepolisian Negara Republik Indonesia Daerah (Kapolda), yang bertanggungjawabkepadaKapolri.

KapoldadibantuolehWakilKapolda

(Wakapolda). Polda membawahi Kepolisian Negara Republik Indonesia Resor (Polres).

Kepolisian Resor (disingkat Polres) adalah struktur komando Kepolisian Republik Indonesia di daerah kabupaten/kota. Kepolisian Resor di wilayah perkotaan biasa disebut "Kepolisian Resor Kota" (Polresta). "Kepolisian Resor Kota Besar" (Polrestabes) biasanya digunakan untuk ibu kota provinsi. Kepolisian Resor dikepalai oleh seorang Kepala Kepolisian Resor (Kapolres), Kepolisian Resort Kota dikepalai oleh seorang Kepala KepolisianResor
Kota (Kapolresta) dan Kepolisian Resor Kota Besar dikepalai oleh seorang Kepala Kepolisian Resort Kota Besar (Kapolrestabes). Polres memiliki satuan tugas kepolisian yang lengkap, layaknya Polda, dan dipimpin oleh seorang Komisaris Besar Polisi (Kombes) (untuk Polrestabes) atau Ajun Komisaris BesarPolisi (AKBP) (untuk Polres/Polresta).

\section{B. Administrasi Kewilayahan Polisi}

Pembagian administrasi kewilayahan Polisi dari tingkat paling rendah yaitu:

1. POLSEK: Kepolisian Sektor, membawahkan 1 Kecamatan, dipimpin oleh polisi berpangkat AKP (Ajun Komisaris Polisi), (Kompol untuk Polda Jaya)

2. POLRES: Kepolisian Resor, membawahkan 1 Kabupaten, dipimpin oleh polisi berpangkat AKBP (Ajun Komisaris Besar Polisi) dan Kompol (Komisaris Polisi)

3. POLWIL: Kepolisian Wilayah, biasanya membawahkan beberapa kabupaten/kota sekaligus, dipimpin oleh polisi berpangkat KOMBES (Komisaris Besar).

4. POLDA: Kepolisian Daerah, membawahkan 1 propinsi, dipimpin oleh polisi berpangkat Brigjen (Brigadir Jenderal)/Irjen (Inspektur Jenderal), (Irjen biasanya untuk daerah stategis)

5. Mabes POLRI: Markas Besar Kepolisian Republik Indonesia, membawahkan seluruh daerah di Indonesia, dipimpin oleh KAPOLRI berpangkat Jenderal Polisi.

\section{Sistem Pendukung Keputusan}

Sistem Pendukung Keputusan (SPK) adalah bagian dari sistem informasi berbasis komputer termasuk sistem berbasis pengetahuan atau manajemen pengetahuan yang dipakai untuk mendukung pengambilan keputusan dalam suatu organisasi atau perusahaan. Dapat juga dikatakan sebagai sistem komputer yang mengolah data menjadi informasi untuk mengambil keputusan dari masalah semi terstruktur yang spesifik. [2]-[5]-[7]

\section{Metode Simple Additive Weighting}

Metode SAW sering dikenal dengan istilah metode penjumlahan terbobot. Konsep dasar metode SAW (Simple Additive Weighting) adalah mencari penjumlahan terbobot dari rating kinerja pada setiap alternatif pada semua atribut. Metode SAW dapat membantu dalam pengambilan keputusan suatu kasus, akan tetapi perhitungan dengan menggunakan metode SAW ini hanya yang 
menghasilkan nilai terbesar yang akan terpilih sebagai alternatif yang terbaik. Perhitungan akan sesuai dengan metode ini apabila alternatif yang terpilih memenuhi kriteria yang telah ditentukan. Metode SAW ini lebih efisien karena waktu yang dibutuhkan dalam perhitungan lebih singkat. Metode SAW membutuhkan proses normalisasi matriks keputusan (X) ke suatu skala yang dapat diperbandingkan dengan semua rating alternatif yang ada.[6]-[1]

Formula untuk melakukan normalisasi tersebut adalah sebagai berikut:

$$
r_{i j}=\begin{gathered}
\frac{x_{i j}}{\max _{i} x_{i j}} \text { Jeuntungan adalah atribut } \\
\frac{\max _{i} x_{i j}}{x_{i j}} \text { jika j adalah atribut } \\
\text { biaya cost }
\end{gathered}
$$

Dimana :

$\mathrm{R}_{\mathrm{ij}}=$ Rating kinerja ternormalisasi

$\operatorname{Max}_{\mathrm{ij}}=$ Nilai maksimum dari setiap baris dan kolom

$\operatorname{Min}_{\mathrm{ij}}=$ Nilai minimum dari setiap baris dan kolom

$\mathrm{X}_{\mathrm{ij}}=$ Baris dan kolom dari matriks

Dengan $r_{i j}$ adalah rating kinerja ternormalisasi dari alternatif $A_{i}$ pada atribut $C_{j} ; i=1,2, \ldots, m$ dan $\mathrm{j}=1,2, \ldots, \mathrm{n}$.

$$
V_{i}={ }_{j=i}^{n} W_{j} R_{i j}
$$

Nilai $V_{i}$ yang lebih besar mengindikasikan bahwa alternatif $A_{i}$ lebih terpilih.

Dimana :

$\mathrm{V}_{\mathrm{i}}=$ Nilai akhir dari alternatif

$\mathrm{W}_{\mathrm{i}}=$ Bobot yang telah ditentukan

$\mathrm{R}_{\mathrm{ij}}=$ Normalisasi matriks

\section{E. Pengertian PHP}

PHP Pertama kali ditemukan pada 1995 oleh seorang Software Developer bernama Rasmus Lerdrof. Ide awal PHP adalah ketika itu Radmus ingin mengetahui jumlah pengunjung yang membaca resume onlinenya. script yang dikembangkan baru dapat melakukan dua pekerjaan, yakni merekam informasi visitor, dan menampilkan jumlah pengunjung dari suatu website. Dan sampai sekarang kedua tugas tersebut masih tetap populer digunakan oleh dunia web saat ini. Kemudian, dari situ banyak orang di milis mendiskusikan script buatan Rasmus Lerdrof, hingga akhirnya rasmus mulai membuat sebuah tool/script, bernama Personal Home Page (PHP).[3]
PHP adalah sebuah bahasa pemrograman berbasis web yang mempunyai banyak keunggulan dibandingkan dengan bahasa pemrograman berbasis web yang lain.

\section{F. Pengertian MySQL}

MySQL adalah sendiri merupakan suatu jalan untuk dapat menyimpan berbagai informas dengan membaginya berdasarkan kategorikategori tertentu. Dimana informasi-informasi tersebut saling berkaitan, satu dengan yang lainnya.

MySQL bersifat RDBMS (Relational Database Management System) RDBMS memungkinkan seorang admin dapat menyimpan banyak informasi ke dalam tabletable, dimana table-table tersebut saling berkaitan satu sama lain. Keuntungan RDBMS sendiri adalah kita dapat memecah database kedalam table-table yang berbeda. setiap table memiliki informasi yang berkaitan dengan table yang lainnya.[3]

\section{III.METODE PENELITIAN}

\section{A. Lokasi Penelitian}

Penelitian ini dilaksanakan di Medan, Sumatera Utara, dikarenakan saat ini termasuk wilayah administrasi Kepolisian terbesar di Indonesia. Polda Sumu terklarifikasi sebagai Polda tipe A, sehingga seorang Kapolda yang menjabat haruslah perwira tinggi (Pati) berpangkat Irjen (Inspektur Jenderal). Wilayah hukum Polda Sumut terdiri dari Kabupaten Kota Madya yang dijabat oleh Kapolresta dan wilayah Kabupaten Daerah Tingkat II (Dati II) yang dijabat oleh Kapolres. Polresta dan Polres di jajaran Polda Sumut terdiri dari :
1. Polres Belawan
2. Pores Tanah Karo
3. Polres Langkat
4. Polresta Binjai
5. Polresta Gunung Sitoli
6. Polres Nias
7. Polres Nias Selatan
8. Polres Nias Barat
9. Polres Nias Utara
10. Polres Mandailing Natal
11. Polresta Sibolga
12. Polres Tapanuli Tengah
13. Polres Tapanuli Selatan
14. Polres Tapanuli Utara
15. Polres Padang Lawas
16. Polres Padang Lawas Utara
17. Polresta Tebing Tinggi
18. Polres Batubara
19. Polres Humbang Hasundutan
20. Polres Dairi
21. Polres Samosir 
22. Polres Toba Samosir

23. Polres Deli Serdang

24. Polres Serdang Bedagai

25. Polresta Tanjungbalai

26. Polres Labuhan Batu

27. Polres Labuhan Batu Utara

28. Polres Labuhan Batu Selatan

29. Polresta Pematang Siantar

30. Polres Simalungun

31. Polres Pakpak Bharat

32. Polresta Padang Sidimpuan

33. Polres Asahan

\section{B. Jenis Dan Sumber Data}

Data yang digunakan untuk menyusun penelitian dalam pemilihan calon Kapolres ini adalah data sekunder yang dipublikasikan oleh Karo SDM (Kepala Biro SDM) Polda Sumut dan Instansi Pemerintah terkait lainnya. Data publikasi Karo SDM Polda Sumut terutama adalah data daftar Perwira Menengah (Pamen) pada jajaran Polda Sumut.

\section{Teknik Pengumpulan Data}

Dalam penelitian ini teknik pengumpulan data yang penulis gunakan adalah teknik dokumentasi dan wawancara yaitu berupa pengumpulan data dengan mengajukan pertanyaan langsung kepada seorang ahli atau yang berwenang dalam suatu masalah dan berupa buku-buku yang memuat data-data tentang struktur Kepolisian Republik Indonesia.

\section{Pemilihan Jabatan Kapolres}

Kepolisian Resort yang selanjutnya disingkat Polres adalah pelaksana tugas dan wewenang Polri di wilayah kabupaten/kota yang berada di bawah Kapolda". Polres bertugas menyelenggarakan tugas pokok Polri dalam memelihara keamanan dan ketertiban masyarakat, menegakkan hukum, serta memberikan perlindungan, pengayoman, dan pelayanan kepada masyarakat dan melaksanakan tugas-tugas Polri lainnya dalam daerah hukum Polres, sesuai dengan ketentuan peraturan perundang-undangan (Perkap No.23 Tahun 2010 tentang Susunan Organisasi dan Tata Kerja pada Tingkat Polres dan Polsek). Polres mempunyai pimpinan, dalam Pasal 8 Peraturan Kepala Kepolisian R.I. Nomor 23 Tahun 2010 tentang Susunan Organisasi dan Tata Kerja pada Tingkat Kepolisian Resort dan Kepolisian Sektor dijelaskan mengenai unsur pimpinan Polres. Adapun bunyi pasal persebut, adalah sebagai berikut: Unsur pimpinan sebagaimana dimaksud Kapolres dan Wakpolres.Untuk pemilihan Kapolres dilakukan oleh Mabes Polri atas rekomendasi dan seleksi yang di lakukan di Kepala polisi Daerah Sumatera Utara (Kapolda Sumut).

Kriteria-kriteria yang digunakan dalam pemilihan calon Kapolres adalah sebagai berikut:

Tabel 1.Criteria

\begin{tabular}{ll}
\hline Kode & Criteria \\
\hline C1 & Perwira Polri berpangkat Kompol dan AKBP \\
C2 & Memiliki Masa Dinas Perwira (MDP) \\
C3 & $\begin{array}{l}\text { Memiliki Masa Dinas Dalam Pangkat } \\
\text { (MDDP) Kompol }\end{array}$ \\
C4 & Jenjang Pendidikan \\
C5 & Usia \\
C6 & Kesehatan Fisik dan Mental \\
\hline
\end{tabular}

\section{E. Analisa Model Penilaian Penentuan Jabatan Kapolres}

Berdasarkan faktor-faktor yang dipertimbangkan dalam penempatan personil, maka ditetapkan criteria -criteria yang dinilai dalam proses penilaian penentuan jabatan Kapolres. Adapun model penilaian penentuan jabatan Kapolres ditunjukkan pada tabel-tabel berikut ini

\begin{tabular}{|c|c|c|c|c|}
\hline No & Criteria & Penilaian & Skor & $\begin{array}{c}\text { Bobot } \\
(\%)\end{array}$ \\
\hline \multirow[t]{3}{*}{1.} & Pangkat: & & & \multirow{3}{*}{30} \\
\hline & $\triangle \quad \mathrm{AKBP}$ & & 100 & \\
\hline & 囚 Kompol & & 80 & \\
\hline
\end{tabular}

Tabel 3. Model Penilaian Memiliki Masa Dinas

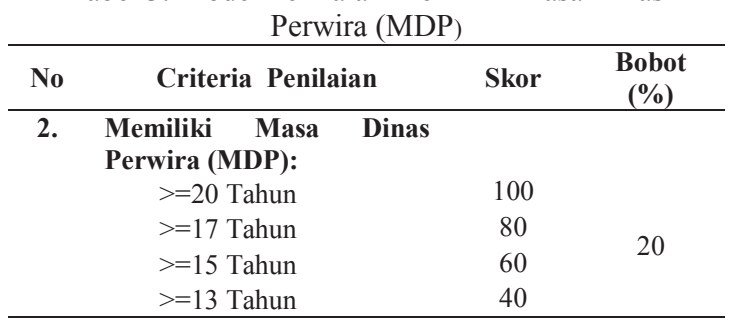

Tabel 4. Model Penilaian Memiliki Masa Dinas

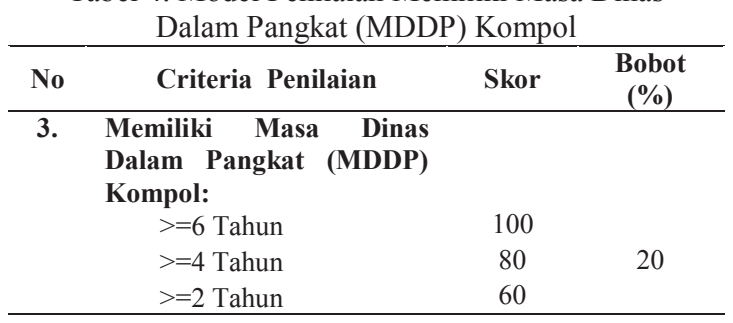

Tabel 5. Model Penilaian Jenjang Pendidikan

\begin{tabular}{|c|c|c|c|}
\hline No & Criteria Penilaian & Skor & $\begin{array}{c}\text { Bobot } \\
(\%)\end{array}$ \\
\hline \multirow[t]{3}{*}{4.} & Jenjang Pendidikan: & & \multirow{3}{*}{10} \\
\hline & $\triangle \quad$ Doktor (S3) & 100 & \\
\hline & $\otimes \quad$ Magister (S2) & 80 & \\
\hline
\end{tabular}




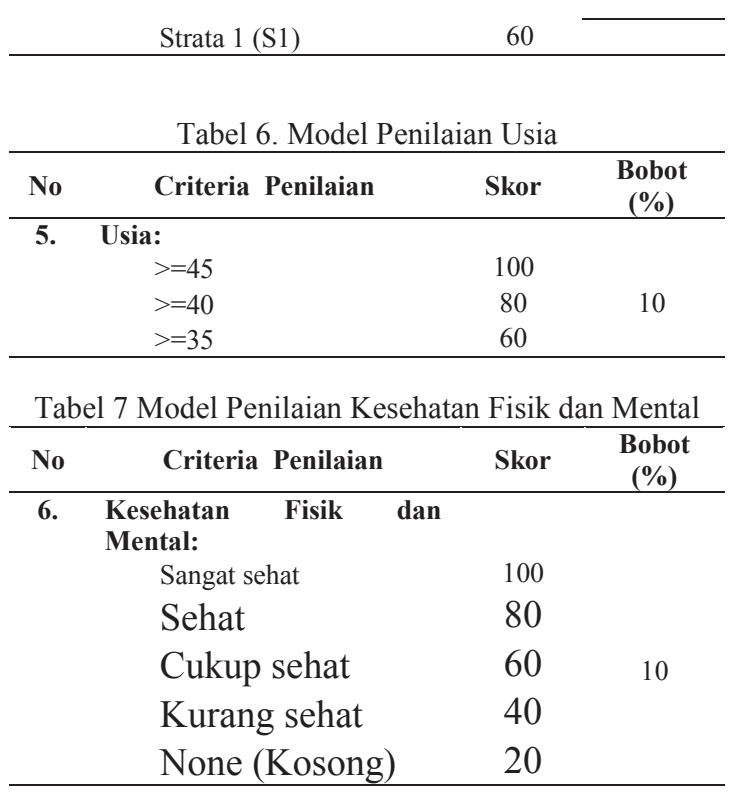

\section{F. Penerapan metode Simple Additive} Weight (SAW)

Markas Besar Kepolisian Negara Republik Indonesia (Mabes Polri) atas rekomendasi Kepolisian Daerah Sumatera Utara (Kapolda Sumut) melakukan pergantian jabatan Kapolres. Untuk menentukan jabatan Kapolres tersebut ditentukan beberapa criteria penilaian, antara lain sebagai berikut:

a. Pangkat : Ajun Komisaris Besar Polisi (AKBP), Komisaris Polisi (Kompol, masing-masing bobot nilai sudah ditunjukkan pada tabel diatas.

b. Memiliki Masa Dinas Perwira (MDP) Minimal 13 Tahun

c. Memiliki Masa Dinas Dalam Pangkat (MDDP) Kompol Minimal 2 Tahun

d. Jenjang Pendidikan: Doktor (S3), Magister (S2) Dan Sarjana(S1)

e. Usia : $>=45$ Tahun, $>=40$ Tahun dan $>=35$ Tahun

f. Kesehatan Fisik dan Mental : Sangat sehat, sehat, cukup sehat, kurang sehat dan None (kosong).

Alternatif dari personil yang menjadi kandidat bakal calon Kapolres adalah sebanyak 6 (enam) orang yaitu sebagai berikut:

Tabel 8. Alternative

\begin{tabular}{ll}
\hline Kode & Nama \\
Alternative & Siti Marlina \\
\hline A1 & Edward E. Tumanggor \\
A2 & Estomihi Situmorang \\
A3 & Herison Manullang \\
A4 & Josmer Samsuardi Manurung \\
A5 & Mariana Sari \\
A6 & \\
\hline
\end{tabular}

- $\quad$ Bobot untuk setiap criteria adalah sebagai berikut :

$[30 \%, 20 \%, 20 \%, 10 \%, 10 \%, 10 \%]$

- Masukkan alternatif/calon Kapolres dan

Bobot Penilaian Criteria pada tabel.

Ditunjukkan pada tabel dibawah ini:

Tabel 9. Bobot Nilai Setiap Alternative

\begin{tabular}{|c|c|c|c|c|c|c|}
\hline \multirow{2}{*}{$\begin{array}{c}\text { Nama/ } \\
\text { Alternative }\end{array}$} & \multicolumn{6}{|c|}{ Criteria Penilaian } \\
\hline & $\mathrm{C} 1$ & $\mathrm{C} 2$ & $\mathrm{C} 3$ & $\mathrm{C} 4$ & $\mathrm{C} 3$ & $\mathrm{C} 4$ \\
\hline Siti Marlina & 78 & 67 & 89 & 47 & 89 & 47 \\
\hline $\begin{array}{l}\text { Edward } \\
\text { Tumanggor }\end{array}$ & 87 & 50 & 88 & 80 & 88 & 80 \\
\hline $\begin{array}{l}\text { Estomohi } \\
\text { Situmorang }\end{array}$ & 80 & 76 & 84 & 50 & 84 & 50 \\
\hline $\begin{array}{l}\text { Herison } \\
\text { Manullang }\end{array}$ & 76 & 77 & 79 & 60 & 79 & 60 \\
\hline $\begin{array}{l}\text { Josmer S. } \\
\text { Manurung }\end{array}$ & 80 & 89 & 80 & 85 & 86 & 88 \\
\hline Mariana Sari & 75 & 80 & 77 & 82 & 81 & 86 \\
\hline
\end{tabular}

- Perhitungan metode SAW sebagai berikut:

1. Normalisasi menggunakan formula dibawah ini:

$$
R i j=\frac{X_{i j}}{\operatorname{Max} X_{i j}}
$$

Nilai maksimal setiap criteria :

$$
\begin{aligned}
& \mathrm{C} 1=87 \\
& \mathrm{C} 2=89 \\
& \mathrm{C} 3=89 \\
& \mathrm{C} 4=85 \\
& \mathrm{C} 5=89 \\
& \mathrm{C} 6=88
\end{aligned}
$$

\begin{tabular}{|c|c|c|c|c|c|c|}
\hline & C1 & C2 & C3 & C4 & C3 & C4 \\
\hline A1 & $78 / 87$ & $67 / 89$ & $89 / 89$ & $47 / 85$ & $89 / 89$ & $47 / 88$ \\
\hline A2 & $87 / 87$ & $50 / 89$ & $88 / 89$ & $80 / 85$ & $88 / 89$ & $80 / 88$ \\
\hline A3 & $80 / 87$ & $76 / 89$ & $84 / 89$ & $50 / 85$ & $84 / 89$ & $50 / 88$ \\
\hline A4 & $76 / 87$ & $77 / 89$ & $79 / 89$ & $60 / 85$ & $79 / 89$ & $60 / 88$ \\
\hline A5 & $80 / 87$ & $89 / 89$ & $80 / 89$ & $85 / 85$ & $86 / 89$ & $88 / 88$ \\
\hline A6 & $75 / 87$ & $80 / 89$ & $77 / 89$ & $82 / 85$ & $81 / 89$ & $86 / 88$ \\
\hline
\end{tabular}

2. Membuat matriks untuk normalisasi sebagai berikut:

3. Hasil dari normalisasi adalah sebagai berikut:

\begin{tabular}{|c|c|c|c|c|c|c|}
\hline $\mathbf{A 1}$ & $\mathbf{C 1}$ & $\mathbf{C 2}$ & $\mathbf{C 3}$ & $\mathbf{C 4}$ & $\mathbf{C 3}$ & $\mathbf{C 4}$ \\
\hline $\mathbf{A 2}$ & 0,90 & 0,75 & 1,00 & 0,55 & 1,00 & 0,53 \\
\hline $\mathbf{A 3}$ & 0,90 & 0,56 & 0,99 & 0,94 & 0,99 & 0,91 \\
\hline $\mathbf{A 4}$ & 0,87 & 0,85 & 0,94 & 0,59 & 0,94 & 0,57 \\
\hline $\mathbf{A 5}$ & 0,92 & 1,00 & 0,90 & 1,00 & 0,97 & 1,00 \\
\hline $\mathbf{A 6}$ & 0,86 & 0,90 & 0,87 & 0,96 & 0,91 & 0,98 \\
\hline$-0,99$ & 0,71 & 0,89 & 0,68 \\
\hline-
\end{tabular}

Nilai bobot criteria $(W)$ : Criteria $\quad$ Bobot 


\begin{tabular}{|l|l|}
\hline $\mathbf{C} 1$ & $30 \%$ \\
\hline $\mathbf{C} 2$ & $20 \%$ \\
\hline $\mathbf{C} 3$ & $20 \%$ \\
\hline $\mathbf{C} 4$ & $10 \%$ \\
\hline $\mathbf{C 5}$ & $10 \%$ \\
\hline $\mathbf{C 6}$ & $10 \%$ \\
\hline Jumlah & $\mathbf{1 0 0 \%}$ \\
\hline
\end{tabular}

Nilai bobot criteria $=[30,20,20,10,10,10]$ $\mathbf{V}=\mathbf{W} * \mathbf{R}$

Dimana : $\mathbf{V}=$ Perfernsi; $\mathbf{W}=$ Bobot criteria $; \mathbf{R}$ $=$ Matriks hasil normalisasi

$$
\begin{aligned}
\mathrm{A} 1=(0.3 * 0.90)+(0.20 * 0.75)+(0.20 * 1.00) \\
+(0.1 * 0.55)+(0.1 * 1.00)+ \\
(0.1 * 0.53)=0,83
\end{aligned}
$$

$$
\begin{aligned}
& \mathrm{A} 2=(0.3 * 1.00)+(0.20 * 0.56)+(0.20 * 0.99) \\
&+(0.1 * 0.94)+(0.1 * 0.99)+(0.1 * \\
&0.91)=0.89
\end{aligned}
$$

\begin{tabular}{|c|c|c|c|c|c|c|c|c|}
\hline \multirow{2}{*}{$\begin{array}{c}\mathrm{Al} \\
\text { ter } \\
\mathrm{Na} \\
\text { tiv } \\
\mathrm{e}\end{array}$} & \multicolumn{6}{|c|}{ Criteria penilaian } & \multirow{2}{*}{$\begin{array}{c}\mathrm{Ha} \\
\text { sil }\end{array}$} & \multirow{2}{*}{$\begin{array}{l}\text { Ra } \\
\text { nk }\end{array}$} \\
\hline & $\mathrm{C} 1$ & $\mathrm{C} 2$ & $\mathrm{C} 3$ & $\mathrm{C} 4$ & $\mathrm{C} 3$ & $\mathrm{C} 4$ & & \\
\hline A1 & 0,27 & 0,15 & 0,20 & 0,06 & 0,10 & 0,05 & $\begin{array}{c}0,8 \\
3\end{array}$ & 6 \\
\hline A2 & 0,30 & 0,11 & 0,20 & 0,09 & 0,10 & 0,09 & $\begin{array}{c}0,8 \\
9\end{array}$ & 3 \\
\hline A3 & 0,28 & 0,17 & 0,19 & 0,06 & 0,09 & 0,06 & $\begin{array}{c}0,8 \\
5\end{array}$ & 4 \\
\hline A4 & 0,26 & 0,17 & 0,18 & 0,07 & 0,09 & 0,07 & $\begin{array}{c}0,8 \\
4\end{array}$ & 5 \\
\hline A5 & 0,28 & 0,20 & 0,18 & 0,10 & 0,10 & 0,10 & $\begin{array}{c}0,9 \\
5\end{array}$ & 1 \\
\hline A6 & 0,26 & 0,18 & 0,17 & 0,10 & 0,09 & 0,10 & $\begin{array}{c}0,9 \\
0\end{array}$ & 2 \\
\hline
\end{tabular}

$$
\begin{aligned}
& \mathrm{A} 3=(0.3 * 0.92)+(0.20 * 0.85)+(0.20 * 0.94) \\
&+(0.1 * 0.59)+(0.1 * 0.94)+(0.1 * \\
&0.57)=0,85
\end{aligned}
$$

$$
\begin{aligned}
& \mathrm{A} 4=(0.3 * 0.87)+(0.20 * 0.87)+(0.20 * 0.89) \\
&+(0.1 * 0.71)+(0.1 * 0.89)+(0.1 * \\
&0.68)=0,84
\end{aligned}
$$

$$
\begin{gathered}
\mathrm{A} 5=(0.3 * 0.92)+(0.20 * 1.00)+(0.20 * 0.90) \\
+(0.1 * 1.00)+(0.1 * 0.97)+(0.1 * \\
1.00)=0,95
\end{gathered}
$$

$$
\begin{gathered}
\mathrm{A} 6=(0.3 * 0.86)+(0.20 * 0.90)+(0.20 * 0.87) \\
+(0.1 * 0.96)+(0.1 * 0.91)+(0.1 * \\
0.98)=0,90
\end{gathered}
$$

Tabel 10. Hasil Perankingan

Maka dari hasil perhitungan perfernsi dapat ditentukan siapa yang akan menjadi calon Kapolres yaitu dengan nilai tertinggi $(\mathbf{0 , 9 5})$ atas nama Josmer S. Manurung.

\section{IV.IMPLEMENTASI DAN PENGUJIAN}

\section{A. Implementasi}

Setelah sistem dianalisis dan didesain secara rinci, maka akan menuju tahap implementasi. Implementasi merupakan tahap meletakkan sistem sehingga siap untuk dioperasikan. Implementasi bertujan untuk mengkonfirmasi modul-modul perancangan, sehingga pengguna dapat memberikan masukan kepada pembangunan sistem.

B. Implementasi Antarmuka Sistem

1. Implementasi Halaman Login

Form login digunakan untuk masuk kedalam aplikasi atau operasi selanjutnya. Apabila login admin berhasil, maka akan masuk kedalam halaman utama, tetapi apabila login admin tidak berhasil maka akan ada peringatan dengan menampilkan pesan bahwa login admin gagal atau username dan password salah.

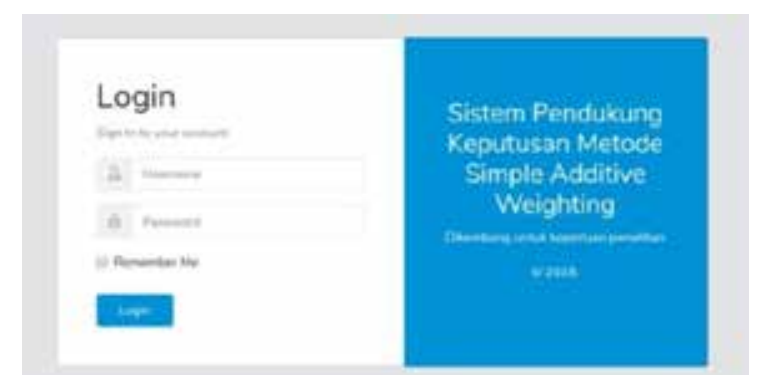

Gambar1. Halaman Login Admin

\section{Implementasi Halaman Dashboard}

Halaman dashboard digunakan untuk menampilkan halaman induk dari sistem yang didalamnya terdapat integrasi antar halaman yang terhubung kedalam halaman dashboard. Halaman dashboard ini juga berfungsi untuk mengontrol semua halaman web.

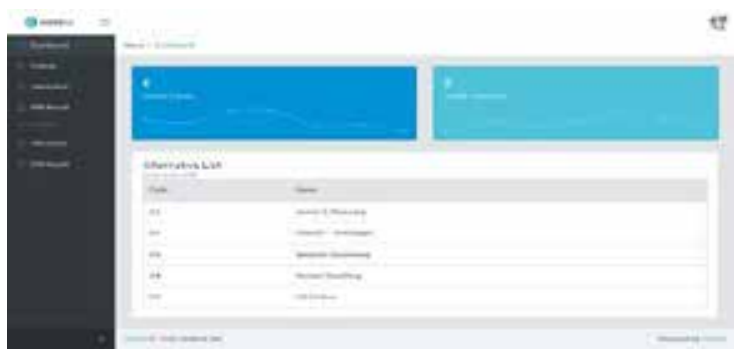

Gambar 2. Halaman Dashboard

\section{Implementasi Halaman Hasil Uji SPK}

Halaman hasil uji SPK ini digunakan untuk menampilkan hasil proses uji nilai criteria dari calon Kapolres. Halaman ini menampilkan nama calon Kapolres, nilai masing-masing criteria beserta nilai akhir dari metode SAW. Implementasi halaman hasil uji SPK dapat dilihat pada gambar dibawah ini: 


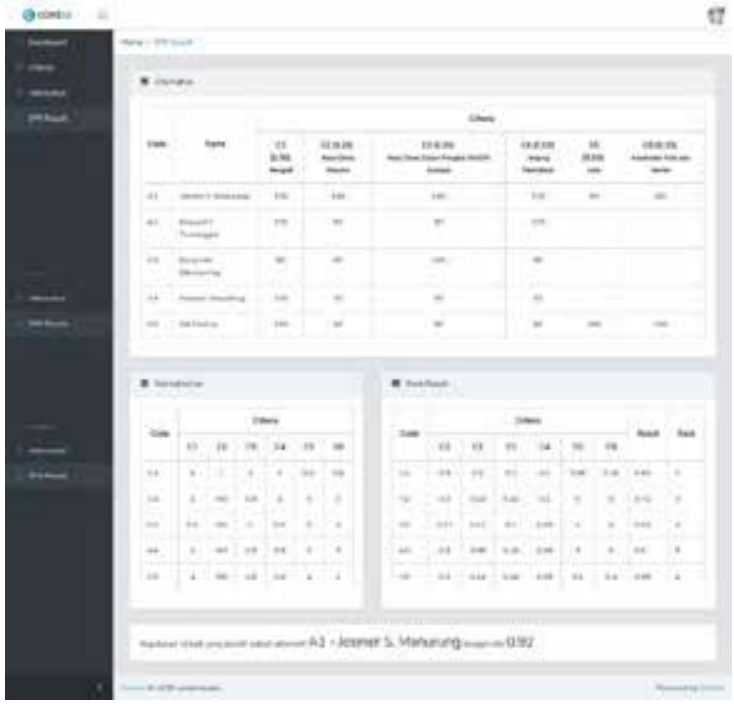

Gambar 3. Halaman Hasil Uji SPK

\section{Pengujian Sistem}

Pengujian sistem akan mengamati semua aktifitas input, proses dan output sistem dalam bentuk data/modul/halaman yang diamati, hasil yang diharapkan dan hasil pengujian.

\section{Pengujian Halaman Login}

Hasil pengujian terhadap halaman login admin dapat dilihat pada tabel 11 berikut ini:

Tabel 11. Pengujian Halaman Login Admin

\begin{tabular}{lllll}
\hline $\begin{array}{l}\text { N } \\
\text { o }\end{array}$ & $\begin{array}{l}\text { Data } \\
\text { Yang } \\
\text { Diuji }\end{array}$ & $\begin{array}{l}\text { Hasil Yang } \\
\text { Diharapka } \\
\text { n }\end{array}$ & $\begin{array}{l}\text { Hasil } \\
\text { Pengujia } \\
\text { n }\end{array}$ & $\begin{array}{l}\text { Keteranga } \\
\mathbf{n}\end{array}$ \\
\hline 1 & Input & Data & & Dapat \\
& usernam & $\begin{array}{l}\text { diterima } \\
\text { dengan }\end{array}$ & Sesuai & $\begin{array}{l}\text { masuk ke } \\
\text { halaman } \\
\text { utama } \\
\end{array}$ \\
e dan & menekan & & sistem \\
& passwor & tombol & & \\
\end{tabular}

\section{Pengujian Halaman Alternative}

Hasil pengujian terhadap halaman input alternative dapat dilihat pada tabel 12 berikut ini:

Tabel 12. Pengujian Halaman Input Alternative

\begin{tabular}{|c|c|c|c|c|}
\hline $\begin{array}{l}\mathbf{N} \\
\mathbf{0}\end{array}$ & $\begin{array}{l}\text { Data } \\
\text { Yang } \\
\text { Diuji } \\
\end{array}$ & $\begin{array}{l}\text { Hasil Yang } \\
\text { Diharapkan }\end{array}$ & $\begin{array}{l}\text { Hasil } \\
\text { Penguji } \\
\text { an }\end{array}$ & Keterangan \\
\hline 1 & $\begin{array}{l}\text { Halaman } \\
\text { input } \\
\text { alternati } \\
\text { ve }\end{array}$ & $\begin{array}{l}\text { Setelah } \\
\text { alternative } \\
\text { calon } \\
\text { diinput } \\
\text { maka akan } \\
\text { disimpan } \\
\text { kedalam } \\
\text { tabel calon } \\
\text { dengan } \\
\text { menekan } \\
\text { tombol } \\
\text { "Save" }\end{array}$ & Sesuai & $\begin{array}{l}\text { Data calon } \\
\text { Kapolres } \\
\text { langsung } \\
\text { tersimpan } \\
\text { kedalam } \\
\text { database }\end{array}$ \\
\hline 2 & Halaman & Setelah & Sesuai & Alternative \\
\hline
\end{tabular}

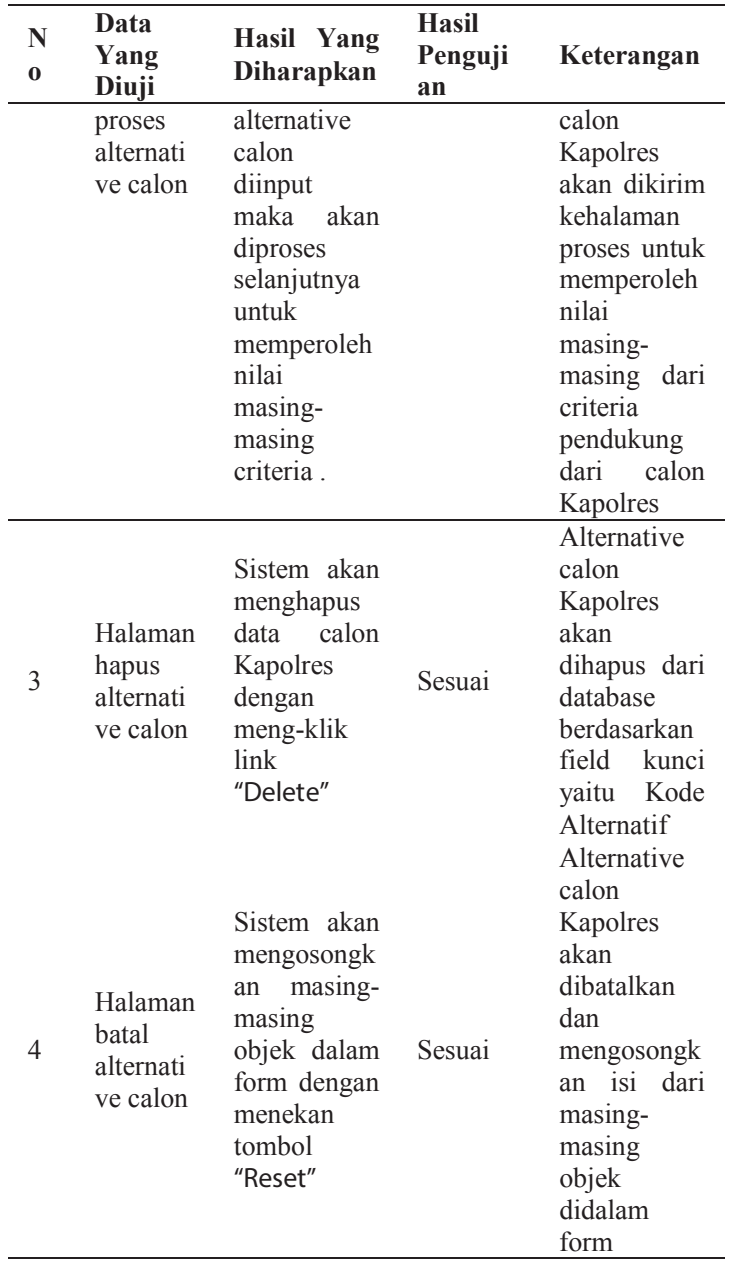

\section{Pengujian Halaman Criteria}

Hasil pengujian terhadap halaman input criteria dapat dilihat pada tabel 13 berikut ini:

\begin{tabular}{|c|c|c|c|c|}
\hline $\begin{array}{l}\mathbf{N} \\
\mathbf{0}\end{array}$ & $\begin{array}{l}\text { Data } \\
\text { Yang } \\
\text { Diuji }\end{array}$ & $\begin{array}{l}\text { Hasil Yang } \\
\text { Diharapkan }\end{array}$ & $\begin{array}{l}\text { Hasil } \\
\text { Pengujia } \\
\text { n }\end{array}$ & Keterangan \\
\hline 1 & $\begin{array}{l}\text { Halama } \\
\mathrm{n} \text { input } \\
\text { criteria }\end{array}$ & $\begin{array}{l}\text { Setelah } \\
\text { criteria } \\
\text { diinput maka } \\
\text { criteria akan } \\
\text { disimpan } \\
\text { kedalam } \\
\text { database } \\
\text { dengan } \\
\text { menekan } \\
\text { tombol } \\
\text { "save" } \\
\end{array}$ & Sesuai & $\begin{array}{l}\text { Data criteria } \\
\text { langsung } \\
\text { tersimpan } \\
\text { kedalam } \\
\text { database }\end{array}$ \\
\hline 2 & $\begin{array}{l}\text { Halama } \\
\mathrm{n} \\
\text { proses } \\
\text { biodata } \\
\text { calon }\end{array}$ & $\begin{array}{l}\text { Setelah } \\
\text { biodata calon } \\
\text { diinput maka } \\
\text { akan } \\
\text { diproses } \\
\text { selanjutnya } \\
\text { untuk } \\
\text { memperoleh } \\
\text { nilai masing- } \\
\text { masing }\end{array}$ & Sesuai & $\begin{array}{l}\text { Biodata } \\
\text { calon } \\
\text { Kapolres } \\
\text { akan dikirim } \\
\text { kehalaman } \\
\text { proses untuk } \\
\text { memperoleh } \\
\text { nilai masing- } \\
\text { masing dari } \\
\text { criteria }\end{array}$ \\
\hline
\end{tabular}




\begin{tabular}{|c|c|c|c|c|}
\hline $\begin{array}{l}\mathbf{N} \\
\mathbf{0}\end{array}$ & $\begin{array}{l}\text { Data } \\
\text { Yang } \\
\text { Diuji } \\
\end{array}$ & $\begin{array}{l}\text { Hasil Yang } \\
\text { Diharapkan }\end{array}$ & $\begin{array}{l}\text { Hasil } \\
\text { Pengujia } \\
\text { n }\end{array}$ & Keterangan \\
\hline & & criteria. & & $\begin{array}{l}\text { pendukung } \\
\text { dari calon } \\
\text { Kapolres }\end{array}$ \\
\hline 3 & $\begin{array}{l}\text { Halama } \\
\mathrm{n} \text { hapus } \\
\text { biodata } \\
\text { calon }\end{array}$ & $\begin{array}{l}\text { Sistem akan } \\
\text { menghapus } \\
\text { data calon } \\
\text { Kapolres } \\
\text { dengan } \\
\text { meng-klik } \\
\text { link "Delete" }\end{array}$ & Sesuai & $\begin{array}{l}\text { Biodata } \\
\text { calon } \\
\text { Kapolres } \\
\text { akan dihapus } \\
\text { dari database } \\
\text { berdasarkan } \\
\text { field kunci } \\
\text { yaitu Kode }\end{array}$ \\
\hline 4 & $\begin{array}{l}\text { Halama } \\
\mathrm{n} \text { batal } \\
\text { biodata } \\
\text { calon }\end{array}$ & $\begin{array}{l}\text { Sistem akan } \\
\text { mengosongk } \\
\text { an masing- } \\
\text { masing objek } \\
\text { dalam form } \\
\text { dengan } \\
\text { menekan } \\
\text { tombol } \\
\text { "Reset" }\end{array}$ & Sesuai & $\begin{array}{l}\text { Criteria } \\
\text { Biodata } \\
\text { calon } \\
\text { Kapolres } \\
\text { akan } \\
\text { dibatalkan } \\
\text { dan } \\
\text { mengosongk } \\
\text { an isi dari } \\
\text { masing- } \\
\text { masing objek } \\
\text { didalam } \\
\text { form }\end{array}$ \\
\hline
\end{tabular}

\section{KESIMPULAN}

Berdasarkan hasil pengujian dan evaluasi yang telah dilakukan sebelumnya, maka dapat diperoleh kesimpulan sebagai berikut:

1. Diperlukan instalasi aplikasi untuk setiap perangkat yang akan digunakan untuk proses penentuan jabatan Kapolres.

2. Aplikasi yang dibangun dapat menerapkan metode Simple Additive Weight (SAW).

Aplikasi yang dibangun bisa sebagai tahap awal untuk menentukan keputusan dalam penentuan jabatan Kapolres.

\section{VI.REFERENSI}

[1] Fasillah, Suffi, Sindy; Hindarto. Penerapan Metode Simple Additive Weighting (Saw) Dalam Sistem Pendukung Keputusan Pemilihan Produk Penjualan (Studi kasus : Rumah Tas Cantik Pandaan).Teknik Informatika.,Universitas Muhammadiyah Sidoarjo

[2] Kusumadewi, Sri: Hartati, Sri; Harjoko, Agus; Wardoyo, Retantyo. 2006, Fuzzy Multi-Attribute Decisopn Making (Fuzzy MADM).Yogyakarta : Graha Ilmu.

[3] M. Rudiyanto 2011, Aplikasi Web dengan PHP dan MySQL. Yogyakarta : Andi

[4] Nasution, Nurin, Ardian. 2013, Penerapan Metode Simple Multi Attribute Rating Technique Untuk Penentuan Bintang Nararia Bhayangkara (Studi Kasus : Kepolisian Daerah Riau).Fakultas Sains Dan Teknologi.,Universitas Islam Negeri Sultan Syarif Kasim

[5] Pratamaputraa, Adhitya, Nur Angga; Hidayahb, Nur Aeni dan Waspodoc, Bayu. 2010. Sistem Pendukung Keputusan Kenaikan Jabatan dengan Model AHP pada Biro Kepegawaian di Sekretariat Negara Republik Indonesia. Fakultas Sains dan Teknologi., Universitas Islam Negeri Syarif Hidayatullah Jakarta

[6] Sujarwadi, Asep; Abidin, Zaenal, Dodo. 2016, Perancangan Sistem Pendukung Keputusan Dengan Metode Simple Additive Weighting (Saw) Dalam Penentuan Tunjangan Kinerja Pegawai Pada Kepolisian Resort Kota (Polresta) Jambi. Program Studi Magister Sistem Informasi.,Stikom Dinamika Bangsa, Jambi

[7] Turban, Aronson, Liang. 2005. Decission Support System and Intelligent Systems, Yogyakarta : Andi. 